\title{
A Genome-Wide Scan for Eysenckion Personality Dimensions in Adolescent Twin Sibships: Psychoticism, Extraversion, Neuroticism, and Lie
}

\author{
Nathan A. Gillespie, ${ }^{1,2} \mathrm{Gu} Z \mathrm{Zhu},{ }^{1}$ David M. Evans, ${ }^{1,3}$ \\ Sarah E. Medland, ${ }^{1,2}$ Margie J. Wright, ${ }^{1}$ and \\ Nick G. Martin ${ }^{1}$ \\ ${ }^{1}$ Queensland Institute of Medical Research, Brisbane \\ ${ }^{2}$ Virginia Institute of Psychiatric and Behavioral Genetics \\ ${ }^{3}$ Wellcome Trust Centre for Human Genetics, Oxford
}

\begin{abstract}
We report the first genome-wide scan of adolescent personality. We conducted a genome-wide scan to detect linkage for measures of adolescent Psychoticism, Extraversion, Neuroticism, and Lie from the Junior Eysenck Personality Questionnaire. Data are based on 1,280 genotyped Australian adolescent twins and their siblings. The highest linkage peaks were found on chromosomes 16 and 19 for Neuroticism, on chromosomes 1, 7, 10,13 m, and 18 for Psychoticism, and on chromosomes 2 and 3 for Extraversion.
\end{abstract}

H. J. Eysenck argued that best way to understand behavior is to study human individual differences. In addition to an overview of Eysenck's model, this introduction will review the genetic epidemiology of both adult and adolescent measures of personality. Our focus will be on the genetics of adolescent personality for which much less

These studies have been supported from multiple sources: National Health and Medical Research Council (901061, 950998, 241944), Queensland Cancer Fund, Australian Research Council (A79600334, A79801419, A79906588, DP0212016), Human Frontiers Science Program (RG0154/1998-B), Beyond Blue, and The Eysenck Memorial Fund. Finally, we warmly thank the twins and their family members for their continued support, generosity of time, and for their interest in this research.

Correspondence concerning this article may be sent to Nathan A Gillespie, Virginia Institute of Psychiatric and Behavioral Genetics, Virginia Commonwealth University, Richmond VA 23298-0126; E-mail: ngillespie@vcu.edu.

Journal of Personality 76:6, December 2008

(C) 2008, Copyright the Authors

Journal compilation (C) 2008, Wiley Periodicals, Inc.

DOI: $10.1111 / \mathrm{j} .1467-6494.2008 .00527 . \mathrm{x}$ 
is known. There has been little research to date that has examined, within a developmental framework, the genetic and environmental stability of adolescent personality. Moreover, there have been no attempts to perform tests of genome-wide linkage or association aimed at locating quantitative trait loci responsible for the observed genetic variation in adolescent personality.

Eysenck's chief contribution to psychology was his model of personality, which is based on a quantitative and dimensional representation of human behavior (H. J. Eysenck, 1967, 1971a; H. J. Eysenck \& Rachman, 1965). His model includes three orthogonal dimensions: Psychoticism, Extraversion, and Neuroticism. These dimensions are independent of intelligence and have consistently emerged as second-order or superfactors from large-scale factor analytic studies (H. J. Eysenck, 1971b; H. J. Eysenck \& M. W. Eysenck, 1985; H. J. Eysenck \& S. B. G. Eysenck, 1991). Each superfactor represents a polygenic and hierarchical phenotype that forms a continuum based on a number of first-order traits, which themselves are empirically derived, intercorrelated, and give rise to the superfactors above them (H. J. Eysenck, 1971b; H. J. Eysenck \& M. W. Eysenck, 1985; H. J. Eysenck \& S. B. G. Eysenck, 1975, 1991).

The construct of Psychoticism was first described in detail by H. J. Eysenck and S. B. G. Eysenck (Eysenck \& Eysenck, 1968a, 1968b, 1976) and has subsequently been revised to describe and support the idea that high scorers have a greater probability and risk of psychotic illness (H. J. Eysenck, 1995; H. J. Eysenck \& S. B. G. Eysenck, 1991). They are best described as solitary, not caring for people, troublesome, having difficulty fitting in, cruel and inhumane, lacking feelings and empathy, and altogether insensitive (H. J. Eysenck \& S. B. G. Eysenck, 1991). Despite the scales' intention, evidence suggests that although subjects scoring high on Psychoticism exceed controls on ratings of psychotic like experiences including symptoms of schizotypal and paranoid personality disorder, they are not necessarily at heightened risk for psychosis (Chapman, Chapman, \& Kwapil, 1994). Moreover, unlike Extraversion and Neuroticism, the phenotypic factor structure does not appear to have the same genetic structure, suggesting that the scale may be measuring correlated but heterogenous factors or facets (Heath \& Martin, 1990).

Similar to Jung's construct with the same name, Extraversion is a quantitative trait that more or less defines sociability (H. J. Eysenck, 1953, 1967; H. J. Eysenck \& S. B. G. Eysenck, 1991). High scorers 
like parties, have many friends, and need to have people to talk to (H. J. Eysenck \& S. B. G. Eysenck, 1991). This dimension has been used to differentiate hysterical (extraverted neurotic) from dysthymic (introverted neurotic) neurotic disorders (H. J. Eysenck, 1947, 1957). It has been associated with liability to suicidality, depression, panic, and phobic disorders, schizophrenia (Berenbaum \& Fujita, 1994; Bienvenu et al., 2001; Janowsky, 2001; Roy, 1998) and can also differentiate between bi- and unipolar patients (Bagby et al., 1997).

Neuroticism was originally conceptualized as a quantitative personality trait defining an individual's vulnerability to various neurotic disorders and psychological distress (H. J. Eysenck, 1953, 1967). Individuals with high Neuroticism are characterized with "emotional instability" and are prone to low self-esteem, feelings of anxiety, depression, and guilt (H. J. Eysenck \& S. B. G. Eysenck, 1991). The dimension is also highly significant of a number of clinical mood and affect disorders (Kirk et al., 2000). H. J. Eysenck has argued that there is strong evidence to support the discontinuity between neuroses and psychoses (H. J. Eysenck, 1960, 1970; H. J. Eysenck \& S. B. G. Eysenck, 1969, 1976), and so the dimensions were psychometrically designed to reflect this discontinuity $(\mathrm{H}$. J. Eysenck \& S. B. G. Eysenck, 1975). Indeed, his personality model can be used to differentiate individuals as normal, neurotic, and psychotic (including persons with schizophrenia and manic depression; H. J. Eysenck \& S. B. G. Eysenck, 1991). This does not preclude individuals scoring high on Neuroticism from scoring high (or low) on the other dimensions, and any combination is possible. The revised Eysenck Personality Questionnaire (EPQ-R) also includes a Lie scale, which, in addition to measuring social conformity, can reflect deliberate faking, presentation of an ideal self-concept rather than a candid self-appraisal or an honest but inaccurate self-assessment (H. J. Eysenck \& S. B. G. Eysenck, 1991; S. B. G. Eysenck \& H. J. Eysenck, 1970; Michaelis \& Eysenck, 1971).

\section{Genetic Epidemiology}

Evidence for the genetic contribution to individual differences in adult personality is compelling and comes from a variety of sources: twin pairs reared together (Eaves \& Young, 1981; Loehlin \& Nichols, 1976; Macaskill, Hopper, White, \& Hill, 1994; Rose \& Kaprio, 1988; Rose, Kaprio, Williams, Viken, \& Obremski, 1990; 
Rose, Koskenvuo, Kaprio, Sarna, \& Langinvainio, 1988); separated twin pairs (Bouchard, Lykken, McGue, Segal, \& Tellegen, 1990; Pedersen, Plomin, McClearn, \& Friberg, 1988; Shields, 1962; Tellegen et al., 1988); non-twin adoptees and their biological and adoptive families (Loehlin, 1982, 1985; Loehlin, Horn, \& Willerman, 1981; Scarr, Webber, Weinberg, \& Wittig, 1981); as well as twin pairs reared together and their relatives, that is, parents, siblings, spouses, adult children (Eaves, 1976; Eaves, Heath, Neale, Hewitt, \& Martin, 1998; Lake, Eaves, Maes, Heath, \& Martin, 2000; Price, Vandenberg, Iyer, \& Williams, 1982). Among the numerous reports based on twin data that have examined the heritability of Neuroticism and Extraversion, nearly all have arrived at genetic estimates in the vicinity of 50\% (Eaves \& H. J. Eysenck, 1975; Eaves et al., 1999; Eaves et al., 1998; Fanous, Gardner, Prescott, Cancro, \& Kendler, 2002; Floderus-Myrhed, Pedersen, \& Rasmuson, 1980; Heath et al., 1997; Jang, Livesley, \& Vernon, 1996; Jardine, Martin, \& Henderson, 1984; Jinks \& Fulker, 1970; Keller, Coventry, Heath, \& Martin, 2005; Kendler, Neale, Kessler, Heath, \& Eaves, 1993; Macaskill et al., 1994; Martin, Eaves, \& Fulker, 1979; Pedersen et al., 1988; Rose et al., 1988; Saudino, Pedersen, Lichtenstein, McClearn, \& Plomin, 1997; Viken, Rose, Kaprio, \& Koskenvuo, 1994). Larger extended twin studies have reported broad heritability estimates for Extraversion, ranging from $43 \%$ to $50 \%$, and wider estimates for Neuroticism, ranging from $27 \%$ to $61 \%$ (Eaves et al., 1999; Keller et al., 2005; Lake, Eaves, Maes, Heath, \& Martin, 2000).

Few behavior genetic studies have examined the heritability of Psychoticism and Lie (Eaves, 1976; Eaves et al., 1999; Gillespie, Johnstone, Boyce, Heath, \& Martin, 2001; Hay et al., 2001; Heath \& Martin, 1990; Keller et al., 2005; Macaskill et al., 1994; Martin et al., 1979). Gillespie and colleagues (Gillespie et al., 2001) analyzed EPQ-R data from 2,943 adult male and female Australian twins and reported that $40 \%$ and $44 \%$ of the variance in Psychoticism and Lie, respectively, could be explained by additive genetic effects. Keller and colleagues (2005) in their extended adult twin and sibling design ( $N=12,913$ individuals) reported broad heritability estimates ranging from $28 \%$ to $33 \%$ for Psychoticism and from $33 \%$ to $34 \%$ for Lie. Eaves and colleagues' (1999) study of adult twin and family members $(N=29,691$ individuals) reported broad heritability estimates ranging from $8 \%$ to $29 \%$ for Psychoticism and from $29 \%$ to $42 \%$ for Lie. In all cases, the genetic contribution to adult person- 
ality was significant, whereas the contribution of shared environmental or cultural effects was mostly negligible. In other words, the environmental contribution to individual differences in personality was almost entirely limited to aspects of the environment that were unique and unshared between sibling and family members.

Although adult personality appears phenotypically stable, much less is known about its genetic stability. This is because of the lack of longitudinal and genetically informative data sets; most research has been based on data sets that were either longitudinal but genetically uninformative or genetically informative but cross-sectional (Conley, 1984; Eaves, H. J. Eysenck, \& Martin, 1989; Ormel \& Rijsdijk, 2000; Watson \& Clark, 1984). However, several lines of evidence suggest that not only are genetic effects significant but they are also stable over time, at least with respect to Neuroticism and Extraversion (Eaves et al., 1989; Kendler et al., 1993; Viken et al., 1994). Indeed, Eaves and colleagues (1989) have argued that (a) there is little to support the idea that different genes are expressed at different ages in adults, (b) the effects are strongest for Neuroticism and Extraversion, and (c) any apparent changes in adult gene expression are more likely to be a function of reinforcement augmenting earlier inherited personality differences (Eaves et al., 1989). Viken and colleagues (1994) in the their analyses based on 15,000 male and female Finnish twins, aged 18 to 53 years, also found that there was little evidence for new genetic contributions to individual differences after age 30 , in contrast to significant new environmental effects emerging at every age period. The most recent evidence, based on 20,000 adult individuals who completed the EPQ Neuroticism up to four times over 22 years, reported an average genetic correlation of 0.91 , again suggesting a very high degree of genetic stability in the adult measure (Wray, Birley, Sullivan, Visscher, \& Martin, 2007).

Similar results of high genetic correlations over time have been found for adolescent personality. Gillespie and colleagues (2004) administered the Junior Eysenck Personality Questionnaire (JEPQ; Eaves et al., 1989; H. J. Eysenck \& S. B. G. Eysenck, 1975; S. B. G. Eysenck, 1972) to over 540 twin pairs at ages 12, 14, and 16 years. Multivariate analyses revealed that familial aggregation, with the exception of Lie, was entirely explained by additive genetic effects at each age. Moreover, the genetic factor correlations across time were very high, and after fitting genetic simplex models (see Boomsma, Martin, \& Molenaar, 1989; Boomsma \& Molenaar, 1987; Eaves, 
Long, \& Heath, 1986) to the same data, Gillespie and colleagues found that for each dimension, not only were the JEPQ dimensions stable over time but that large proportions of the additive genetic variance observed at ages 16 and 14 could be explained by genetic effects at age 12. Despite evidence for smaller but significant genetic innovations at ages 14 and 16, their results are consistent with a pleiotropic model of gene action whereby the same genes explain variation across different time points within each of the adolescent personality dimensions.

\section{Aim}

Demonstrating heritability is the necessary precursor for locating and identifying quantitative traits loci (QTL), and since Cloninger's first genome wide scan of Harm Avoidance (1998), there has been a growing impetus to locate quantitative traits loci (QTL) for personality (Benjamin, Ebstein, \& Lesch, 1998; Boomsma et al., 2000; Dina et al., 2005; Ebstein, 2006; Fullerton et al., 2003; Kirk et al., 2000; Levinson, 2006; Nash et al., 2004; Neale, Sullivan, \& Kendler, 2005; Zohar et al., 2003). Although there is some converging evidence for linkage signals from more than one genome scan (Levinson, 2006), all of these studies have been based on adult samples, and nearly all have focused on Neuroticism because of its significant genetic covariance with anxiety and depression (Jardine et al., 1984; Kendler et al., 1993). Yet, despite the evidence for significant heritability and developmental stability in the observed genetic effects for all three dimensions including Lie, no attempts have been made to locate QTLs underpinning variation in adolescent personality. This is largely because the required genotypic information has only until recently become available. The Brisbane Adolescent Twin Study (Wright \& Martin, 2004) now includes adolescent twins and siblings with genome-wide linkage and repeated JEPQ measures. These data, although unselected, are ideal for fitting univariate and multivariate linkage models to detect QTLs. Moreover, because several groups have demonstrated that multivariate methods are a powerful means of detecting QTLs that can influence a set of phenotypes pleiotropically (Amos, de Andrade, \& Zhu, 2001; Boomsma, 1996; Boomsma \& Dolan, 1998; Evans et al., 2004; Martin, Boomsma, \& Machin, 1997), the repeated JEPQ measures will provide a unique opportunity to model QTL effects within a developmental framework. 
Therefore, the aim of this study is to run genome-wide linkage on measures of adolescent Psychoticism, Extraversion, Neuroticism, and Lie.

\section{METHOD}

\section{Subjects}

Data were collected in three waves as part of ongoing studies into the development of melanocytic naevi (moles) at ages 12 and 14 and of cognition at age 16. The protocols of these studies, which involved in-person testing lasting 2-4 hours, have been described in detail elsewhere (Evans, Frazer, Boomsma, \& Martin, 2001; Gillespie, Evans, Wright, \& Martin, 2004; McGregor et al., 1999; Wright \& Martin, 2004; Wright et al., 2001; Zhu et al., 1999). Briefly, twins and their siblings were enlisted by contacting the principals of primary schools in the greater Brisbane area, by media appeals, and by word of mouth. Informed consent was obtained from all participants and parents prior to testing. The twins were tested as closely as possible to their 12th, 14th, and 16th birthdays. Previous analyses using the same data have shown that this sample is typical of Queensland adolescents with respect to moliness (Zhu et al., 1999) and IQ (Wainwright, Wright, Geffen, Luciano, \& Martin, 2005), which, given the project's aims, allayed any concerns that twins with a higher-than-average mole count were being "volunteered" by their parents for participation.

A total of 503 families participated in this study. Although parents were not phenotyped, their genotypes still contributed to identity by descent (IBD) estimation. Parental genotypes where one or both parents participated were obtained from 96 and 358 families, respectively. The sample consisted of 1,280 twins and their siblings from 82 monozygotic (MZ) and 421 dizygotic (DZ) twin pair families each with 0-2 additional siblings. As shown in Table 1, these data generated a total of 922 quasiindependent sib pairs with complete genotypic and phenotypic information for analysis.

\section{Measures}

At each wave twins, co-twins, and their siblings were asked to complete the full 81-item Junior Eysenck Personality Questionnaire (JEPQ; Eaves et al., 1989; H. J. Eysenck \& S. B. G. Eysenck, 1975; S. B. G. Eysenck, 1972), which assesses the three major dimensions of personality: Psychoticism (P; 17 items), Extraversion (E; 24 items) and Neuroticism (N; 20 items). In addition, the questionnaire contained the 20 -item Lie (L) scale that is a measure of social desirability. All items were scored on a 


\section{Table 1}

Total Number of Quasi-Independent Sib Pairs (Qisp) Based on Monozygotic (Mz) and Dizygotic (Dz) Twin Pair Families With 0 to 2 Additional Siblings. A Total of 502 Families Generated 922 QISPs

\begin{tabular}{lcccc}
\hline & \multicolumn{2}{c}{$\begin{array}{c}\text { Number of Families With } \\
\text { Additional Siblings }(N)\end{array}$} & \\
\cline { 2 - 4 } & $N=0$ & $N=1$ & $N=2$ & QISP $^{\mathrm{a}}$ \\
\hline MZ twin pair families & $1^{\mathrm{b}}$ & 69 & 12 & 105 \\
DZ twin pair families & 274 & 113 & 34 & 817 \\
\hline
\end{tabular}

${ }^{\mathrm{a}}$ Total $\mathrm{QISP}_{\mathrm{DZ}}=$ Number of families $\times(\mathrm{s}-1) / 2$, Total $\mathrm{QISP}_{\mathrm{MZ}}=$ Families $\times(\mathrm{s}-1)$ $(\mathrm{s}-2) / 2$, where $\mathrm{s}=N+2$

${ }^{\mathrm{b}}$ Does not contribute QISP

2-point scale ( $Y e s / N o$ ). In most cases, the JEPQ was administered to siblings once and usually coincident with the first or third interviews when the twins were aged 12 or 16 , respectively. The problem for analysis is how best to cope with age effects for siblings who will usually (but not always) be measured at ages different from twins. Some effort, therefore, was made to measure siblings at the same age as the twins, but this was not often possible.

The three dimensions and the Lie scale can be measured reliably by self-report and are highly stable over time (H. J. Eysenck \& S. B. G. Eysenck, 1991; Gillespie et al., 2004; Kirk et al., 2000; Ormel \& Rijsdijk, 2000; Watson \& Clark, 1984). With the exception of perhaps Psychoticism (see Heath \& Martin, 1990), the Neuroticism and Extraversion scales are also extraordinarily robust in terms of the phenotypic $(\mathrm{H}$. J. Eysenck \& S. B. G. Eysenck, 1991) as well as the latent genetic and environmental factor structures (Heath \& Martin, 1990). Regarding factorial invariance, the dimensions are all identifiable in a diverse range of cultures worldwide and across the socioeconomic spectrum (H. J. Eysenck \& S. B. G. Eysenck, 1983). Neuroticism, in particular, has emerged in every model of personality based on questionnaire measurement and analyses of ratings of psychiatric symptoms where anxiety and depression have emerged as general dysphoric or negative effect factor (Zuckerman, 1999; Zuckerman, Kuhlman, Joireman, Teta, \& Kraft, 1988).

\section{DNA Collection, Zygosity Diagnosis, and Genotyping}

Blood was collected from twins at 12,14, and 16 years of age and where possible from parents and siblings for genotyping. DNA was extracted 
from buffy coats using a modification of the "salt method" (Miller, Dykes, \& Polesky, 1988). For same-sex twin pairs, zygosity was determined by typing nine independent DNA microsatellite polymorphisms plus the $\mathrm{X} / \mathrm{Y}$ amelogenin marker for sex determination by polymerase chain reaction yielding a probability of concordance for all nine markers in DZ twins of less than $10^{-4}$ (Nyholt, 2005). The genome scan consisted of 726 highly polymorphic autosomal microsatellite markers and $31 \mathrm{X}$ linked markers at an average spacing of $5 \mathrm{cM}$ in 539 families (2,360 individuals). The microsatellites consisted of a combination of markers from the ABI-Prism and Weber genotyping sets. Full details of the scan are available in Zhu and colleagues (2004).

\section{Statistical Analysis}

\section{Univariate Analysis}

Our univariate and multivariate analyses are described in detail elsewhere (see Evans et al., 2004). Briefly, multipoint IBD probabilities at each of the autosomal markers were calculated using MERLIN (Abecasis, Cherny, Cookson, \& Cardon, 2002), while IBD probabilities at each marker on chromosome X were calculated in MINX ${ }^{1}$ Standard methods for maximum likelihood analysis of continuous data using variance components (Neale \& Cardon, 1992; Posthuma et al., 2003) were performed in Mx (Neale, 1999). This included modelling the effects of age and sex on the means of each personality dimension. The components of variance, which are hypothesised to account for the correlation in liability between relatives, were parameterized as a function of the variance due to the QTL (Q), to a combined residual polygenic and shared environmental effect $(\mathrm{F})$, and to unique environmental (E) effects. The $\mathrm{F}$ effect was estimated by fixing the sib pair correlation to 0.5 . In the absence of shared environmental effects, $\mathrm{F}$ will largely be an estimate of residual polygenic effects.

The null hypothesis that additive genetic variance caused by a QTL linked to a marker for a given phenotype was zero (i.e., $Q=0$ ) was tested against a model in which $\mathrm{Q}$ was estimated. Twice the difference in natural $\log$ likelihoods between these models is distributed asymptotically as a 50:50 mixture of $\chi^{2}{ }_{1}$ and a point mass at zero and is consequently designated $\chi_{0.1}^{2}$ (Self \& Liang, 1987).

\section{Multivariate Analysis}

The advantage of performing a variance components linkage analysis in $\mathrm{Mx}$ is that data from three time points can be combined to increase the

1. http://www.sph.umich.edu/csg/abecasis/Merlin/reference.html 
power to detect linkage. We fitted two multivariate models to test for linkage. In the first, the factor loadings of the QTL on each personality dimension at 12,14 , and 16 were unconstrained, that is, $\mathrm{q} 1 \neq \mathrm{q} 2 \neq \mathrm{q} 3$ (see Figure 1). Because the true values of some of these parameters under the null hypothesis of no linkage are located on the boundary of the parameter space defined by the alternative hypothesis, the likelihood ratio test statistic is distributed as a complicated mixture of $\chi^{2}$ distributions (Self $\&$ Liang, 1987). In other words, because the degrees of freedom in multivariate applications may be more complicated than in the univariate case (Marlow et al., 2003), we will retain the conservative convention of degrees of freedom being equal to the difference in nested-model parameters for all analyses.

The second test assumes that the QTL is responsible for the same amount of phenotypic variation (unstandardized) at each age by equating the three QTL factor loadings, that is, $\mathrm{q} 1=\mathrm{q} 2=\mathrm{q} 3$. This was equivalent to testing whether the QTL was responsible for the same amount of phenotypic variation at each age. If this were the case, then the test for linkage was whether the (equated) loadings could then be set to zero. Since only one QTL variance component was estimated, the test statistic was distributed as in the univariate case (i.e., a 50:50 mixture of a point mass at zero and $\chi^{2}{ }_{1}$ ). Note that this test is approximately equal to taking the mean of the phenotypes across the three ages and performing a univariate test of linkage on this statistic (Martin et al., 1997). In both cases we modelled the QTL, F, and E effects under a Cholesky framework.

The univariate variance components linkage analysis is used to test for linkage between each marker loci and each of the personality phenotypes at ages 12,14 , and 16 . For univariate analyses, the difference between the two log likelihoods can be converted to a LOD score equivalent to the classical LOD score of parametric linkage analysis (i.e., $\Delta-2 L L \div 4.6$ ) (Williams \& Blangero, 1999). However, since we wish to compare the univariate and multivariate linkage peaks that do not have a simple LOD score equivalent, our results will be graphed using asymptotic $p$-values. We note that the significance levels of the multivariate case are approximate and really ought to be simulated to obtain empirical values, but this is impractical for the multivariate case.

\section{RESULTS}

\section{Genome-Wide Scan Results}

Variance components linkage results based on the combined male and female sample, adjusted for age and sex, are illustrated in Figures 


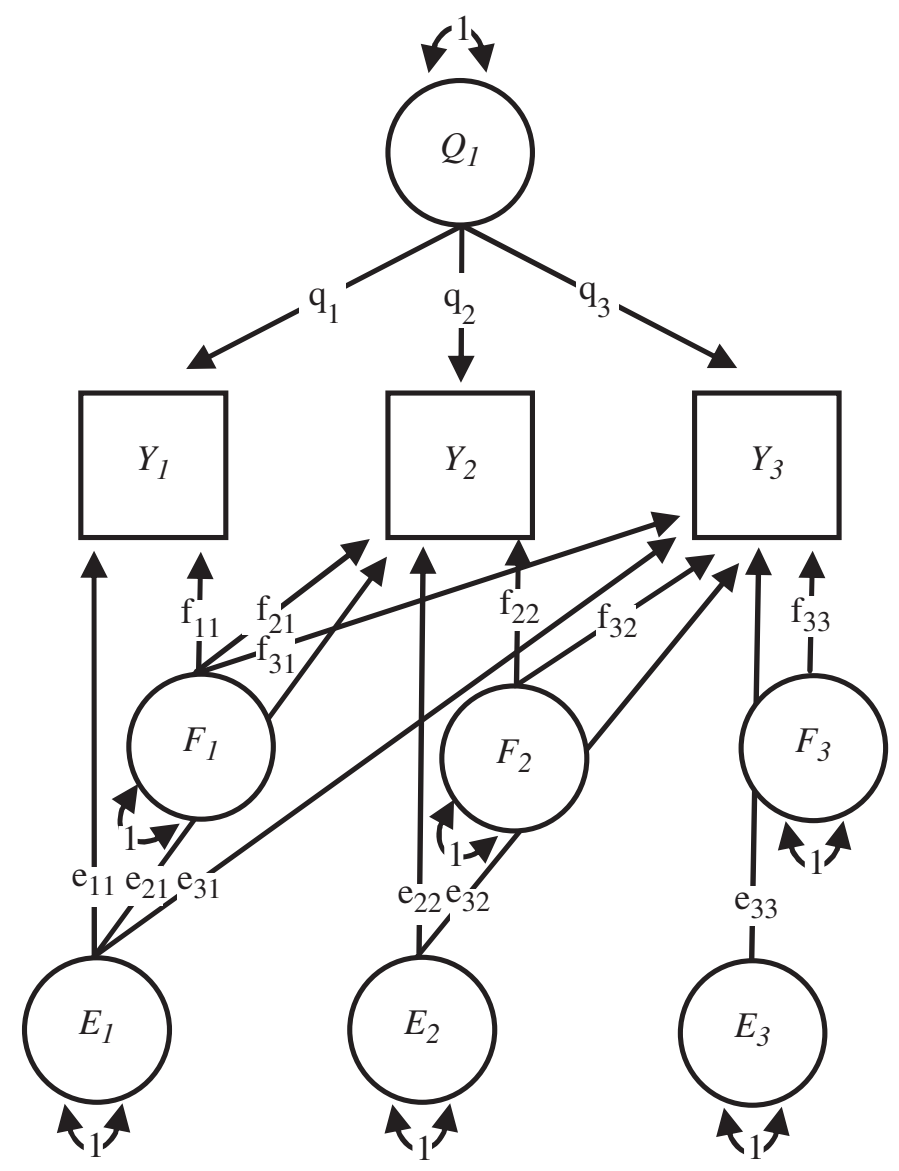

Figure 1

Genetic modelling of personality data. The model includes a Cholesky structure for the familial (F) and nonshared environmental (E) components of variance. The effect of the QTL $\left(Q_{1}\right)$ was also modeled within a Cholesky framework under two conditions: The QTL factor loadings were either constrained $\left(\mathrm{q}_{1}=\mathrm{q}_{2}=\mathrm{q}_{3}\right)$ or allowed to vary $\mathrm{q}_{1}$ \# $\mathrm{q}_{2} \# \mathrm{q}_{3}$.

$2-5$ with a line to denote a nominal $p$-value of 0.001 for suggestive linkage. The plots are defined by the linkage curves on the $y$-axis and the position of each of the markers along the $x$-axis. For the univariate analyses the linkage curves for ages 12, 14, and 16 years are marked red, green, and blue, respectively. This makes it possible to compare the consistency or coincidence of results across measurement occasions. Multivariate $3 d f$ and $1 d f$ linkages are depicted with black and dashed lines, respectively. None of the peaks reached genome-wide significance as defined by Lander and Kruglyak (1995). Based on inspection of the nominal $p$-values, the highest peaks $(p<$ 0.05 ) for Psychoticism, Extraversion, Neuroticism, and Lie are summarized in Table 2 through 5, respectively. For Psychoticism, the 


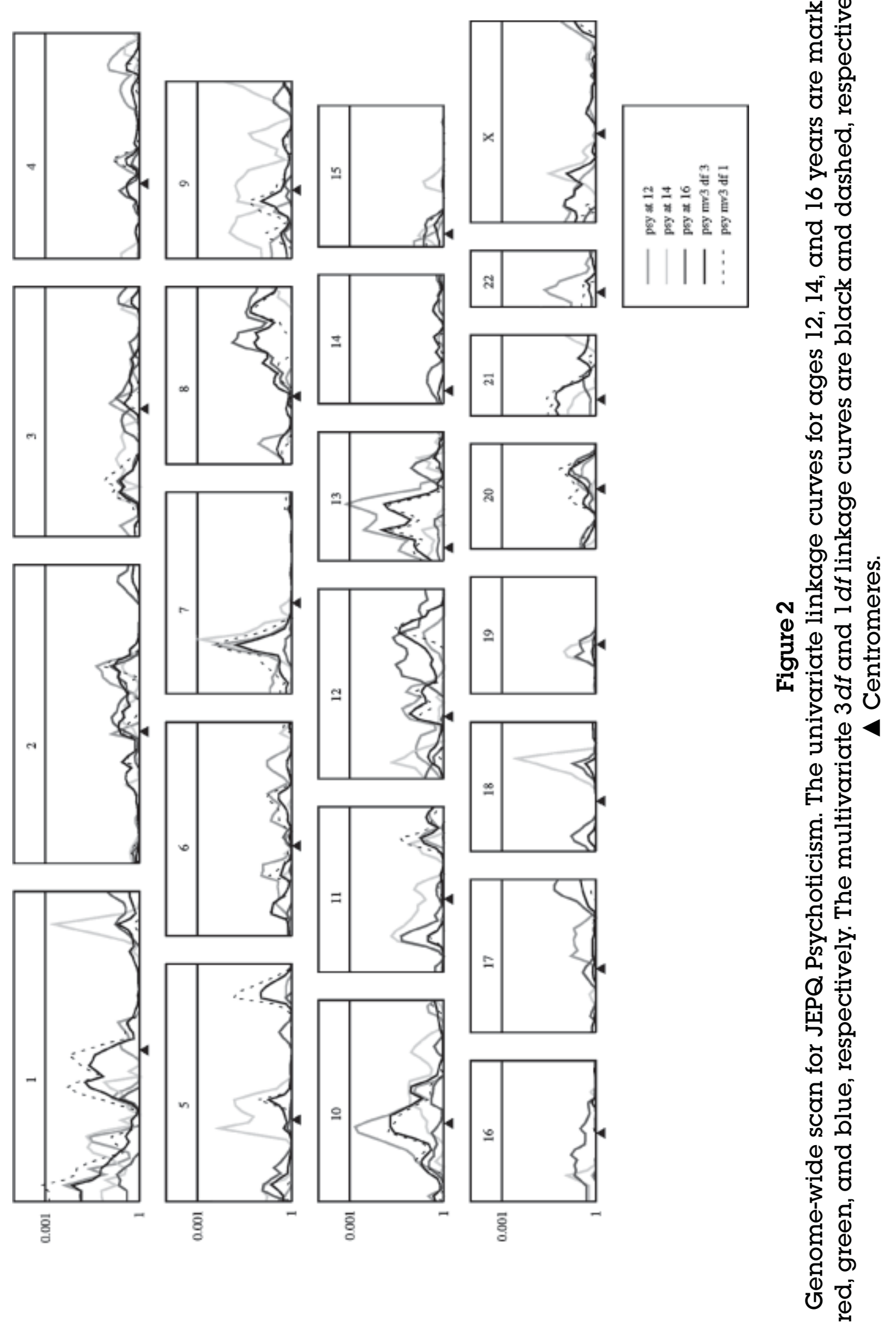




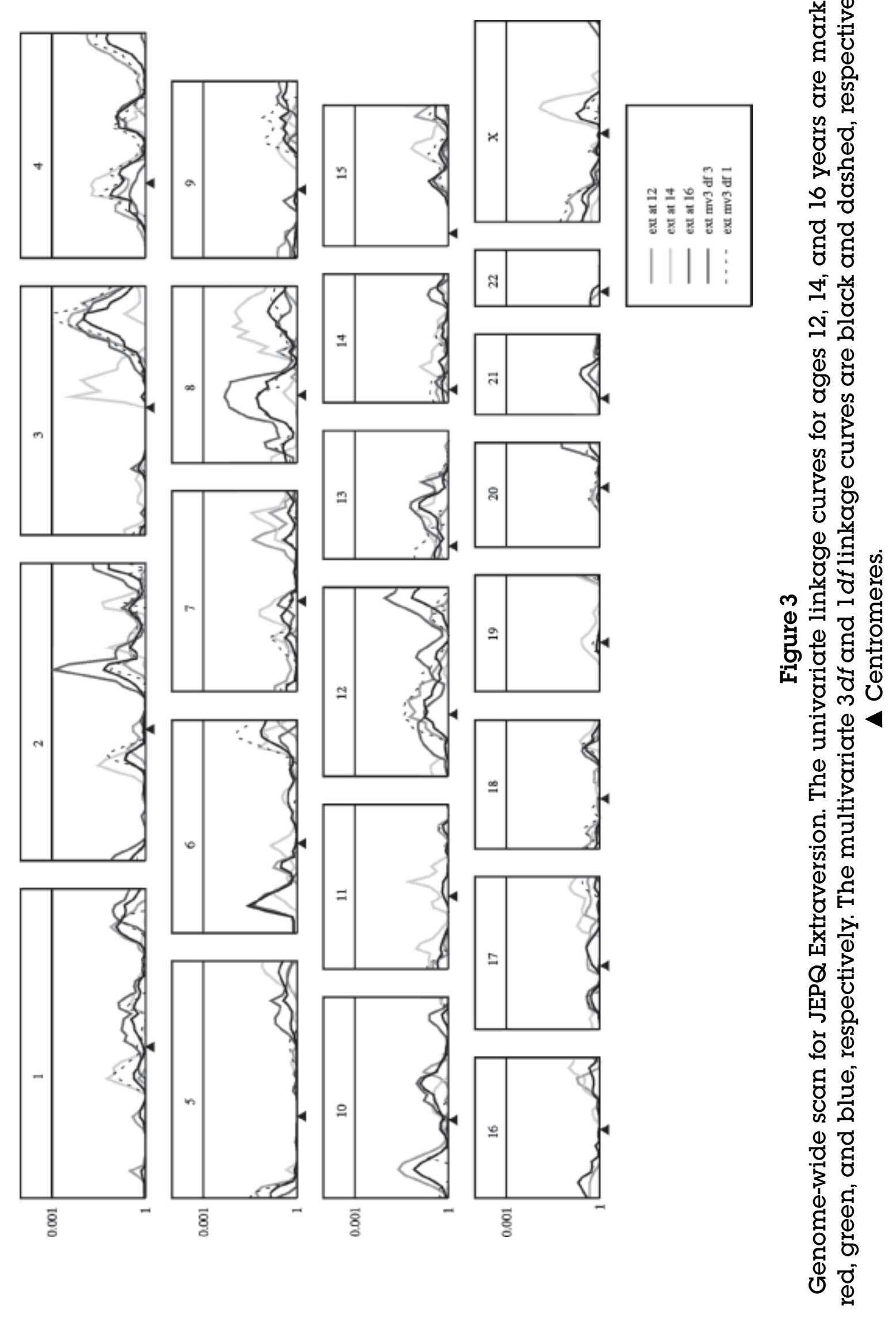




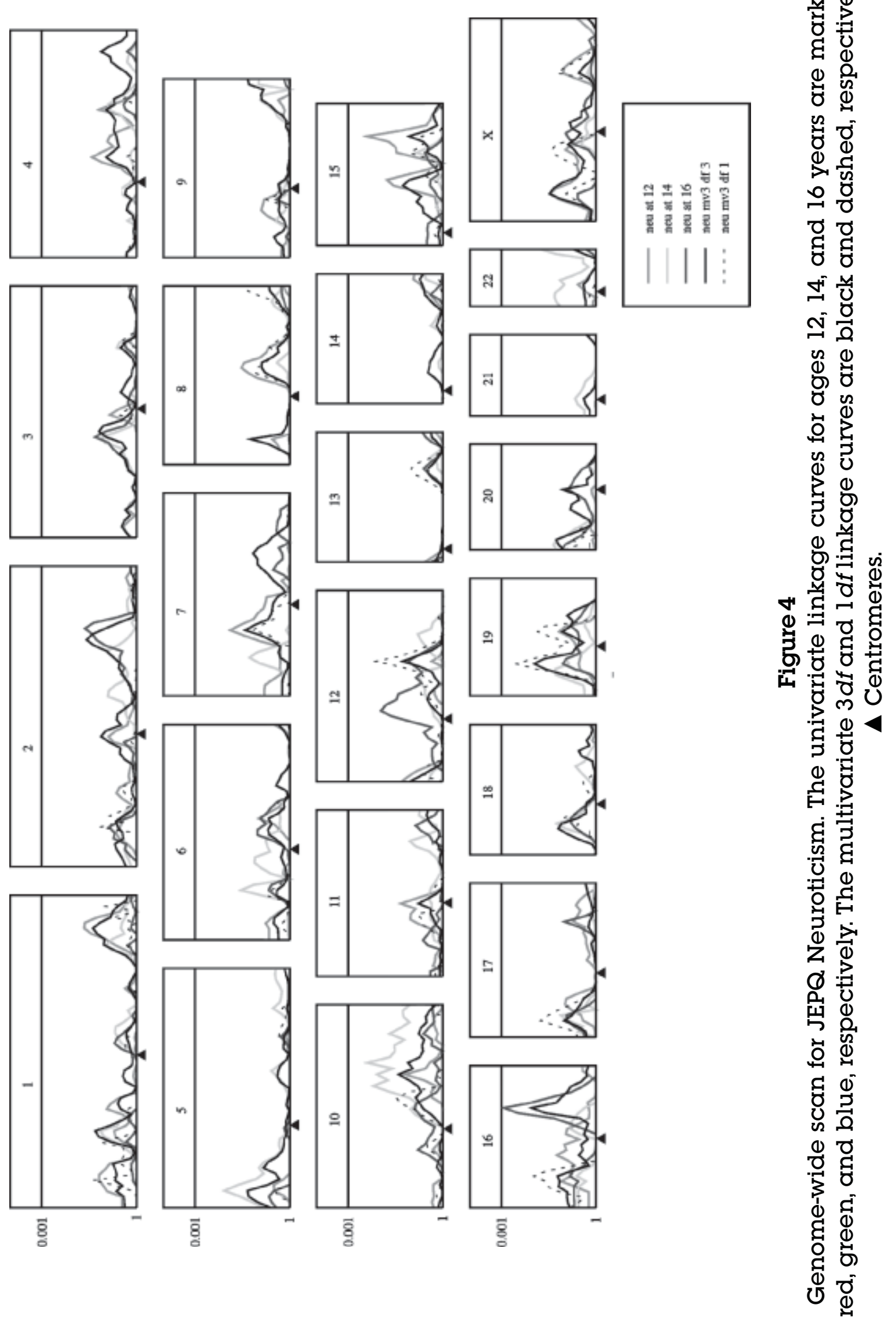




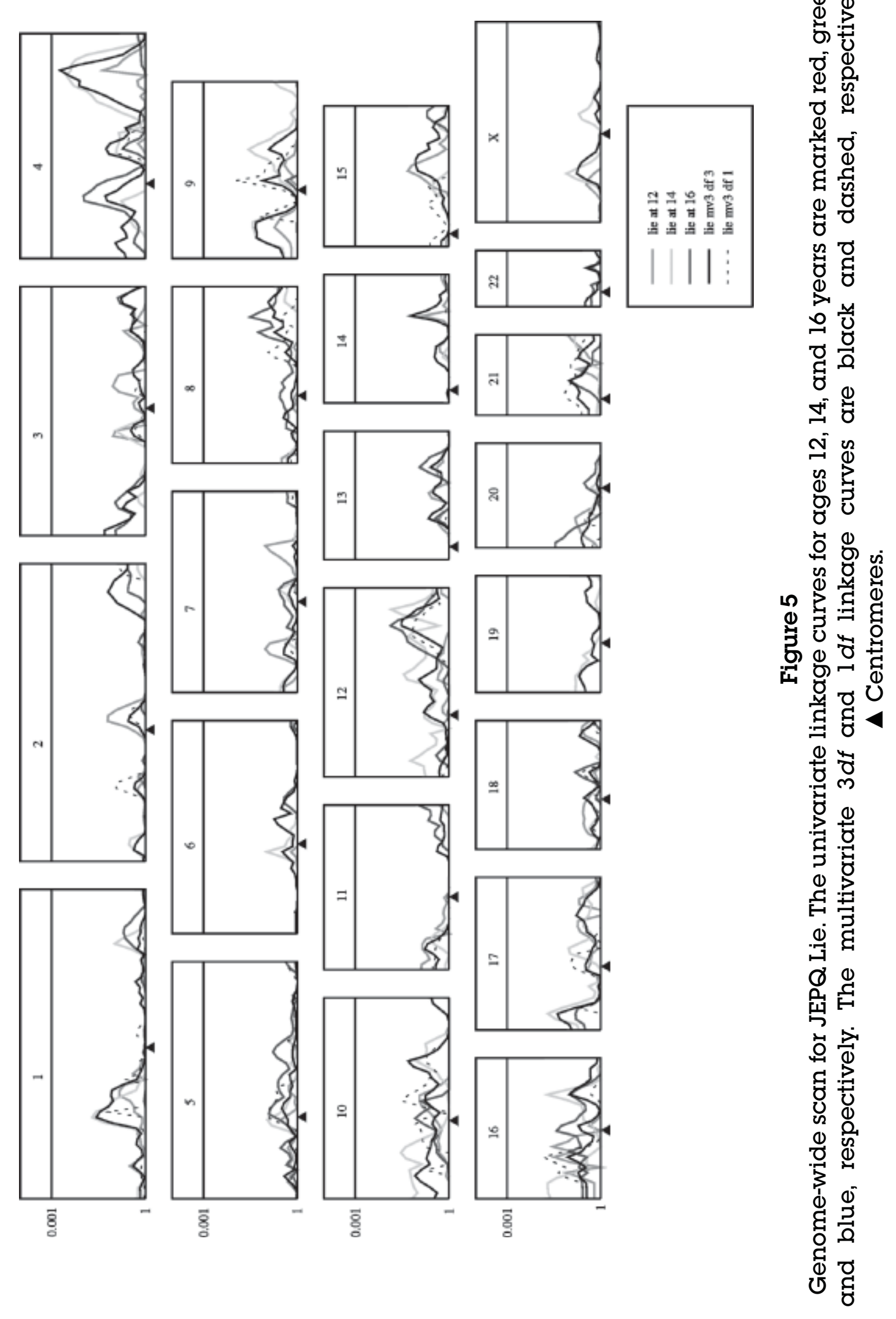


highest peaks were on Chromosomes 1, 5, 7, 9, 10, 13, and 18 (see Figure 2). The linkage curve at 12 years on Chromosome 1 at $15 \mathrm{cM}$ is coincident with the $1 d f$ and $3 d f$ multivariate linkage curves. The region at $45 \mathrm{cM}$ on Chromosome 7 has coincident linkage curves at 12 and 14 years including the $1 d f$ and $3 d f$ multivariate tests. For Extraversion, the highest peaks were on Chromosomes 2, 3, 8, and 12 (see Figure 3). The region between 190 and $200 \mathrm{cM}$ on Chromosome 3 is the most promising because of the coincident linkage peaks at 12 and 16 years as well as the $1 d f$ and $3 d f$ multivariate linkage peaks. For Neuroticism, the highest peaks were on Chromosomes 5, 10, 12, 15, 16, and 19 (see Figure 4). Finally, for Lie, the highest peaks were located on Chromosome 4 (see Figure 5).

\section{DISCUSSION}

To our knowledge, this study is the first genome-wide scan that has been used in an attempt to map genes responsible for variation in adolescent Neuroticism, Extraversion, Psychoticism, and Lie. We found no genes of major effect for any of the JEPQ measures in this linkage sample. This is in line with a recent genome-wide association scan of Neuroticism, which failed to find any loci accounting for more than $1 \%$ of the variance (Shifman et al., 2007). So, despite the advantage of using multivariate modelling to increase the power to detect QTLs, our findings argue the need for larger samples in order to detect QTLs of small effect. Although none of the peaks reached genome-wide significance as defined by Lander and Kruglyak (1995), the highest linkages were observed on Chromosomes 1, 5, 7, 9, 10, 13, and 18 for Psychoticism; on Chromosomes 2, 3, 8, and 12 for Extraversion; on Chromosomes 5, 10, 12, 15, 16, and 19 for Neuroticism; and on Chromosome 4 for Lie.

We used the Online Mendelian Inheritance in $\mathrm{Man}^{2}$ to determine whether any of our highest peaks coincided with those found from previous linkage or association studies of related personality traits or correlated behaviors. We recognize that some may be false positives. For Extraversion, none of our highest peaks were in regions previously investigated by other linkage or association studies

2. http://www.ncbi.nlm.nih.gov/entrez/query.fcgi?db=OMIM 
Eysenckian Personality Dimensions

1431

Table 2

Summary of Major Genome-Wide Linkage Peaks for Psychoticism

\begin{tabular}{|c|c|c|c|c|}
\hline \multirow[b]{2}{*}{ Chromo } & \multicolumn{3}{|c|}{ Psychoticism } & \multirow[b]{2}{*}{$\mathrm{p}$} \\
\hline & $\mathrm{cM}$ & $\operatorname{Age}^{1}$ & $\Delta \chi^{2}$ & \\
\hline \multirow[t]{12}{*}{1} & 0 & $1 d f$ & 10.24 & .001 \\
\hline & 5 & $1 d f$ & 10.41 & .001 \\
\hline & 10 & $1 d f$ & 10.39 & .001 \\
\hline & 15 & 12 & 8.162 & .004 \\
\hline & 15 & $3 d f$ & 12.01 & .007 \\
\hline & 15 & $1 d f$ & 11.34 & .001 \\
\hline & 20 & $1 d f$ & 8.303 & .004 \\
\hline & 30 & $1 d f$ & 6.640 & .010 \\
\hline & 105 & $1 d f$ & 7.841 & .005 \\
\hline & 130 & $1 d f$ & 6.787 & .009 \\
\hline & 135 & $1 d f$ & 7.667 & .006 \\
\hline & 255 & 14 & 9.563 & .002 \\
\hline 5 & 65 & 14 & 7.854 & .005 \\
\hline \multirow[t]{4}{*}{7} & 45 & 12 & 8.316 & .004 \\
\hline & 45 & 14 & 6.701 & .010 \\
\hline & 45 & $1 d f$ & 8.670 & .003 \\
\hline & 50 & 14 & 10.39 & .001 \\
\hline 9 & 170 & 14 & 7.281 & .007 \\
\hline \multirow[t]{4}{*}{10} & 55 & 12 & 7.336 & .007 \\
\hline & 60 & 12 & 9.678 & .002 \\
\hline & 65 & 12 & 10.07 & .002 \\
\hline & 70 & 12 & 8.352 & .004 \\
\hline \multirow[t]{7}{*}{13} & 30 & 12 & 8.879 & .003 \\
\hline & 35 & 12 & 7.974 & .005 \\
\hline & 40 & 12 & 7.262 & .007 \\
\hline & 45 & 12 & 7.279 & .007 \\
\hline & 50 & 12 & 9.062 & .003 \\
\hline & 55 & 12 & 11.26 & .001 \\
\hline & 60 & 12 & 9.100 & .003 \\
\hline 18 & 90 & 14 & 8.826 & .003 \\
\hline
\end{tabular}

${ }^{1}=$ ages 12,14 and 16 as well as multivariate $1 d f$ and $3 d f$

$\Delta \chi^{2}=$ change in chi-square

$\mathrm{cM}=$ centimorgan 
Table 3

Summary of Major Genome-Wide Linkage Peaks for Extraversion

\begin{tabular}{|c|c|c|c|c|}
\hline \multirow[b]{2}{*}{ Chromo } & \multicolumn{3}{|c|}{ Extraversion } & \multirow[b]{2}{*}{$\mathrm{p}$} \\
\hline & $\mathrm{cM}$ & $\mathrm{Age}^{1}$ & $\Delta \chi^{2}$ & \\
\hline \multirow[t]{2}{*}{2} & 170 & 16 & 10.53 & .001 \\
\hline & 175 & 16 & 8.488 & .004 \\
\hline \multirow{15}{*}{3} & 140 & 14 & 6.887 & .009 \\
\hline & 185 & 12 & 7.108 & .008 \\
\hline & 185 & 16 & 6.693 & .010 \\
\hline & 190 & 12 & 8.525 & .004 \\
\hline & 190 & 16 & 7.488 & .006 \\
\hline & 190 & $1 d f$ & 8.815 & .003 \\
\hline & 195 & 12 & 8.556 & .003 \\
\hline & 195 & 16 & 6.705 & .010 \\
\hline & 195 & $3 d f$ & 11.22 & .011 \\
\hline & 195 & $1 d f$ & 10.74 & .001 \\
\hline & 200 & 12 & 8.039 & .005 \\
\hline & 200 & 16 & 6.200 & .013 \\
\hline & 200 & $3 d f$ & 11.14 & .011 \\
\hline & 200 & $1 d f$ & 10.94 & .001 \\
\hline & 205 & $1 d f$ & 7.330 & .007 \\
\hline \multirow[t]{7}{*}{8} & 55 & 16 & 7.326 & .007 \\
\hline & 60 & 16 & 7.534 & .006 \\
\hline & 65 & 16 & 7.938 & .005 \\
\hline & 70 & 16 & 7.759 & .005 \\
\hline & 75 & 16 & 7.312 & .007 \\
\hline & 80 & 16 & 7.141 & .008 \\
\hline & 135 & 14 & 6.794 & .009 \\
\hline 12 & 165 & 16 & 6.832 & .009 \\
\hline
\end{tabular}

${ }^{1}=$ ages 12,14 , and 16 as well as multivariate $1 d f$ and $3 d f$

$\Delta \chi^{2}=$ change in chi-square

$\mathrm{cM}=$ centimorgan

focusing on extraversion or related traits (Carmine et al., 2003; Ebstein, 2006; Golimbet, Gritsenko, Alfimova, \& Ebstein, 2005; Munafo, Yalcin, Willis-Owen, \& Flint, 2007; Ni et al., 2006; Urata et al., 2007). For Psychoticism the linkage peaks between 105 and $135 \mathrm{cM}$ on Chromosome 1 spans the fatty acid amide hydrolase gene 
Eysenckian Personality Dimensions

Table 4

Summary of Major Genome-Wide Linkage Peaks for Neuroticism

\begin{tabular}{rrccc}
\hline & \multicolumn{4}{c}{ Neuroticism } \\
\cline { 2 - 4 } Chromo & $\mathrm{cM}$ & Age $^{1}$ & $\Delta \chi^{2}$ & $\mathrm{p}$ \\
\hline 5 & 15 & 14 & 6.934 & .008 \\
10 & 105 & 14 & 7.495 & .006 \\
& 115 & 14 & 6.963 & .008 \\
12 & 125 & 14 & 8.225 & .004 \\
15 & 110 & $1 d f$ & 7.179 & .007 \\
16 & 100 & 12 & 8.281 & .004 \\
& 90 & 16 & 8.655 & .003 \\
& 95 & 16 & 10.52 & .001 \\
19 & 95 & $3 d f$ & 11.57 & .009 \\
& 100 & 16 & 6.819 & .009 \\
& 30 & $1 d f$ & 8.782 & .003 \\
\hline
\end{tabular}

${ }^{1}=$ ages 12,14 , and 16 as well as multivariate $1 d f$ and $3 d f$

$\Delta \chi^{2}=$ change in chi-square

$\mathrm{cM}=$ centimorgan

Table 5

Summary of Major Genome-Wide Linkage Peaks for Lie

\begin{tabular}{lcccc}
\hline \multirow{4}{*}{ Chromo } & \multicolumn{4}{c}{ Lie } \\
\cline { 2 - 4 } & $\mathrm{cM}$ & Age $^{1}$ & $\Delta \chi^{2}$ & $\mathrm{p}$ \\
\hline 4 & 165 & 14 & 7.767 & .005 \\
& 165 & $3 d f$ & 11.93 & .008 \\
170 & 14 & 8.322 & .004 \\
& 170 & $3 d f$ & 11.84 & .008 \\
175 & 14 & 8.830 & .003 \\
& 175 & $3 d f$ & 13.54 & .004 \\
180 & 14 & 8.255 & .004 \\
180 & $3 d f$ & 14.95 & .002 \\
& 185 & 14 & 8.215 & .004 \\
185 & $3 d f$ & 12.22 & .007 \\
190 & 14 & 7.600 & .006 \\
\hline
\end{tabular}

$1=$ ages 12,14 , and 16 as well as multivariate $1 d f$ and $3 d f$

$\Delta \chi^{2}=$ change in chi-square

$\mathrm{cM}=$ centimorgan 
at 1p35-p34. A missense mutation for this gene has previously been associated with adult problem drug use (Sipe, Chiang, Gerber, Beutler, \& Cravatt, 2002). The peak on Chromosome 5 at $65 \mathrm{cM}$ is in the region of 5p13 and the ADHD4 gene that has shown a weak association with attention deficit hyperactive disorder when based on a sample of 490 affected children (Ogdie et al., 2004). The linkage peaks on Chromosome 13 between 30 and $60 \mathrm{cM}$ span the HTR2A gene at 13q14-q21, which has been associated in adult samples with schizophrenia (Norton \& Owen, 2005), obsessive compulsive disorders (Norton \& Owen, 2005), seasonal affective disorders (Levitan et al., 2002), and alcohol dependence (Hill et al., 2002; Himei et al., 2000). Other reports have found no association between the HT2A polymorphisms and personality traits (Tochigi et al., 2005) or any clear link with psychosis (Mata et al., 2004).

Only four genome-wide studies, all based on adult samples, have included measures of Neuroticism (Fullerton et al., 2003; Kuo et al., 2007; Nash et al., 2004; Neale et al., 2005). A number of other papers have examined related phenotypes and not all have used whole genome-wide scans (Abkevich et al., 2003; Camp et al., 2005; Dina et al., 2005; Holmans et al., 2004; Kaabi et al., 2006; Middeldorp et al., 2007; Thorgeirsson et al., 2003). First, none of the highest Neuroticism peaks was located on or near the serotonin neurotransmitter transporter on Chromosome 17. Among the highest peaks for Neuroticism, two coincided with those reported previously for Neuroticism or related phenotypes (Abkevich et al., 2003; Holmans et al., 2004). The peak on Chromosome 12 at $110 \mathrm{cM}$ is within the region of 12q22-q23.2 and the microsatellite markers D12S1300 and D12S1706, which have been associated with major depression (Abkevich et al., 2003) as well as the Neuroticism peak reported by Fullerton and colleagues (2003). The peak on Chromosome 15 at $100 \mathrm{cM}$ is within $15 \mathrm{q} 25.3-\mathrm{q} 26.2$, which is flanked by markers D15S816 and D15S652. This region has been associated with early-onset major depressive disorder (Holmans et al., 2004). Camp and colleagues (2005) have also found linkage in this region at $97.9 \mathrm{cM}$ for major depression in men. More recently, Kuo and colleagues (2007) reported suggestive linkage in this region at $124 \mathrm{cM}$ based on a sample of 1248 Irish adults. The Kuo study also reported a male-specific suggestive peak on chromosome 16 at $91 \mathrm{cM}$ in the same region as our peak for 16-year-olds. Finally, the linkage peaks for Lie between 165 and $190 \mathrm{cM}$ spans the region between 4q32.2 
and $4 \mathrm{q} 33$ that has been linked to panic (Kaabi et al., 2006) and risk for bipolar disorders (Ginns et al., 1998).

\section{Limitations}

Our results must be interpreted in the context of several important limitations. First, alternate strategies for modeling longitudinal data exist. Previously, we have shown that simplex structures provide an improved fit compared to Cholesky decompositions (Gillespie, Evans, Wright, \& Martin, 2004) but because we did not know what the most appropriate model for the QTL effect was, we therefore fitted an atheoretical Cholesky to model the QTL as well as the F and E effects. Although growth models may be more appropriate, these cannot be fitted to data based on only three data points. Despite evidence of longitudinal genetic continuity for the adolescent dimensions of personality (Gillespie et al., 2004), the lack of congruency or coincidence between the univariate and multivariate linkage peaks, with the exception of Extraversion on Chromosome 3, is likely attributable to the fact that the sample was smaller at the second and third waves. And although modelling of the longitudinal data is normally expected to increase statistical power to detect QTLs (Boomsma, 1996; Evans et al., 2004; Martin, Boomsma, \& Machin, 1997), the current unselected sample was underpowered to detect loci of even moderate effect. Moreover, increases in power normally associated with multivariate analyses will diminish when traits are highly correlated and when there are large amounts of missing data (see Evans et al., 2004) as was the case for our measures at 14 and 16 years. It is also important to remember that traditional designs in which sib pairs are essentially selected at random provide much less power to detect linkage (Risch \& Zhang, 1995), and unless sufficiently large samples can be obtained by way of mailed questionnaires (Kirk et al., 2000; Martin et al., 2000), attempts to detect linkage for complex traits will usually fail if there is only a small phenotypic effect attributable to each locus (Fullerton et al., 2003). Although suggestive linkage peaks are often "tenuous" (see Lander \& Kruglyak, 1995), and indeed many of our highest peaks may be false positives, we nevertheless believe these results are worth reporting now since replication of any peaks in future studies will concentrate focus on certain regions. Moreover, our reported $p$-values can be used as part of weighted false discovery approaches (van den 
Oord, 2005; van den Oord \& Sullivan, 2003) following future whole genome association scans we are currently planning.

\section{CONCLUSION}

To our knowledge, this study is the first to show a genome-wide linkage scan of adolescent personality measures and certainly the first genome-wide scan for the dimensions of Psychoticism, Extraversion, and Lie. Our results are also preliminary, and the sample size and marker density will be substantially increased. Identification of the genes responsible for the genetic variation in adolescent personality would be a major breakthrough in personality research as well as psychiatric genetics insofar as personality is related to mood, affective and psychotic disorders (Battaglia, Przybeck, Bellodi, \& Cloninger, 1996; Benjamin et al., 1998; H. J. Eysenck, 1994, 1995; Jardine, et al., 1984; Kendler et al., 1993; Livesley, 2007; Trull, Tragesser, Solhan, \& Schwartz-Mette, 2007). Therefore, the first step in this process is replicated linkage followed by whole genome-wide association studies in order to provide a firm foundation for fine mapping and gene identification.

\section{REFERENCES}

Abecasis, G. R., Cherny, S. S., Cookson, W. O., \& Cardon, L. R. (2002). Merlinrapid analysis of dense genetic maps using sparse gene flow trees, Nature Genetics, 30(1), 97-101.

Abkevich, V., N., J., C., C., H., H., C., D., N., D., L., R., Hughes, D. C., Plenk, A. M., Lowry, M. R., Richards, R. L., Carter, C., Frech, G. C., Stone, S., Rowe, K., Chau, C. A., Cortado, K., Hunt, A., Luce, K., O’Neil, G., Poarch, J., Potter, J., Poulsen, G. H., Saxton, H., Bernat-Sestak, M., Thompson, V., Gutin, A., Skolnick, M. H., Shattuck, D., \& L., C.-A. (2003). Predisposition locus for major depression at chromosome 12q22-12q23.2. American Journal of Human Genetics, 73, 1271-1281.

Amos, C., de Andrade, M., \& Zhu, D. (2001). Comparison of multivariate tests for genetic linkage. Hum Hered, 51, 133-144.

Bagby, R. M., Bindseil, K. D., Schuller, D. R., Rector, N. A., Young, L. T., Cooke, R. G., et al. (1997). Relationship between the five-factor model of personality and unipolar, bipolar and schizophrenic patients. Psychiatry Res, 70, 83-94.

Battaglia, M., Przybeck, T. R., Bellodi, L., \& Cloninger, C. R. (1996). Temperament dimensions explain the comorbidity of psychiatric disorders. Comprehensive Psychiatry, 37, 292-298. 
Benjamin, J., Ebstein, R. P., \& Lesch, K. P. (1998). Genes for personality traits: Implications for psychopathology. International Journal of Neuropharmacology, 1, 153-168.

Berenbaum, H., \& Fujita, F. (1994). Schizophrenia and personality: Exploring the boundaries and connections between vulnerability and outcome. Journal of Abnormal Psychology, 103, 148-158.

Bienvenu, O. J., Brown, C., Samuels, J. F., Liang, K. Y., Costa, P. T., Eaton, W. W., et al. (2001). Normal personality traits and comorbidity among phobic, panic and major depressive disorders. Psychiatry Res, 102, 73-85.

Boomsma, D. I. (1996). Using multivariate genetic modeling to detect pleiotropic quantitative trait loci. Behavior Genetics, 26, 161-166.

Boomsma, D. I., Beem, A. L., van den Berg, M., Dolan, C. V., Koopmans, J. R., Vink, J. M., et al. (2000). Netherlands twin family study of anxious depression (NETSAD). Twin Research, 3, 323-334.

Boomsma, D. I., \& Dolan, C. V. (1998). A comparison of power to detect a QTL in sib-pair data using multivariate phenotypes, mean phenotypes, and factor scores. Behav Genet, 28, 329-340.

Boomsma, D. I., Martin, N. G., \& Molenaar, P. C. (1989). Factor and simplex models for repeated measures: application to two psychomotor measures of alcohol sensitivity in twins. Behavior Genetics, 19, 79-96.

Boomsma, D. I., \& Molenaar, P. C. (1987). The genetic analysis of repeated measures. I. Simplex models. Behavior Genetics, 17, 111-123.

Bouchard, T. J. Jr., Lykken, D. T., McGue, M., Segal, N. L., \& Tellegen, A. (1990). Sources of human psychological differences: The Minnesota Study of Twins Reared Apart. Science, 250, 223-228.

Camp, N. J., Lowry, M. R., Richards, R. L., Plenk, A. M., Carter, C., Hensel, C. H., et al. (2005). Genome-wide linkage analyses of extended Utah pedigrees identifies loci that influence recurrent, early-onset major depression and anxiety disorders. American Journal of Medical Genetics. Part B, Neuropsychiatric Genetics, 135, 85-93.

Carmine, A., Chheda, M. G., Jonsson, E. G., Sedvall, G. C., Farde, L., Gustavsson, J. P., et al. (2003). Two NOTCH4 polymorphisms and their relation to schizophrenia susceptibility and different personality traits. Psychiatr Genet, 13, 23-28.

Chapman, J. P., Chapman, L. J., \& Kwapil, T. R. (1994). Does the Eysenck psychoticism scale predict psychosis? A ten year longitudinal study. Personality and Individual Differences, 17, 369-375.

Cloninger, C. R., Van Eerdewegh, P., Goate, A., Edenberg, H. J., Blangero, J., Hesselbrock, V., et al. (1998). Anxiety proneness linked to epistatic loci in genome scan of human personality traits. American Journal of Medical Genetics, 81, 313-317.

Conley, J. J. (1984). The hierarchy of consistency: A review and model of longitudinal findings on adult individual differences in intelligence, personality and self-opinion. Personality and Individual Differences, 5, 11-25.

Dina, C., Nemanov, L., Gritsenko, I., Rosolio, N., Osher, Y., Heresco-Levy, U., et al. (2005). Fine mapping of a region on chromosome $8 p$ gives evidence for a QTL contributing to individual differences in an anxiety-related personality trait: TPQ harm avoidance. Am J Med Genet B Neuropsychiatr Genet, 132, 104-108. 
Eaves, L. (1976). A model for sibling effects in man. Heredity, 36, 205-214.

Eaves, L., \& Eysenck, H. J. (1975). The nature of extraversion: A genetical analysis. Journal of Personality and Social Psychology, 32, 102-112.

Eaves, L., Eysenck, H. J., \& Martin, N. G. (1989). Genes, culture, and personality: An empirical approach. London: Academic Press.

Eaves, L., Heath, A., Martin, N., Maes, H., Neale, M., \& Kendler, K. (1999). Comparing the biological and cultural inheritance of personality and social attitudes in the Virginia 30,000 study of twins and their relatives. Twin Research, 2, 62-80.

Eaves, L. J. (1978). Twins as a basis for the causal analysis of human personality. Progress in Clinical and Biological Research, 24A, 151-174.

Eaves, L. J., Heath, A. C., Neale, M. C., Hewitt, J. K., \& Martin, N. G. (1998). Sex differences and non-additivity in the effects of genes on personality. Twin Research, 1, 131-137.

Eaves, L. J., Long, J., \& Heath, A. C. (1986). A theory of developmental change in quantitative phenotypes applied to cognitive development. Behavior Genetics, 16, 143-162.

Eaves, L. J., \& Young, P. A. (1981). Genetic theory and personality differences. In R. Lynn (Ed.), Dimensions of personality (pp. 129-180). Oxford, UK: Pergamon Press.

Ebstein, R. P. (2006). The molecular genetic architecture of human personality: beyond self-report questionnaires. Mol Psychiatry, 11, 427-445.

Evans, D. M., Frazer, I. H., Boomsma, D. I., \& Martin, N. G. (2001). Developmental genetics of red cell indices during puberty: a longitudinal twin study. International Journal of Human Genetics, 1, 41-53.

Evans, D. M., Zhu, G., Duffy, D. L., Montgomery, G. W., Frazer, I. H., \& Martin, N. G. (2004). Multivariate QTL linkage analysis suggests a QTL for platelet count on chromosome 19q. European Journal of Human Genetics, 12, 835-842.

Eysenck, H. J. (1947). Dimensions of personality. New York: Praeger.

Eysenck, H. J. (1953). The structure of human personality. London: Methuen.

Eysenck, H. J. (1957). The dynamics of anxiety and hysteria. New York: Praeger. Eysenck, H. J. (1960). Behavior therapy and the neuroses. New York: Pergamon Press.

Eysenck, H. J. (1967). The biological basis of personality. Springfield, Ill: Charles C. Thomas.

Eysenck, H. J. (1970). The structure of human personality (3rd ed.). London: Mentuen.

Eysenck, H. J. (1971a). The differentiation between normal and various neurotic groups on the Maudsley Personality Inventory. In H. J. Eysenck (Ed.), Readings in introversion and extraversion: Fields of application (Vol. 2, pp. 220-230). London: Staples Press.

Eysenck, H. J. (1971b). Relation between intelligence and personality. Perceptual motor skills, 32, 637-638.

Eysenck, H. J. (1994). Normality and abormality and the three-factor model of personality. In S. Strack \& M. Lorr (Eds.), Differentiating normal and abnormal personality. New York: Springer. 
Eysenck, H. J. (1995). Genius: The natural history of creativity. Cambridge: Cambridge University Press.

Eysenck, H. J., \& Eysenck, M. W. (1985). Personality and individual differences: A natural science approach. New York: Plenum Press.

Eysenck, H. J., \& Eysenck, S. B. G. (1968a). A factorial study of psychoticism as a dimensions of personality. Multivariate Behaviour Research, 15-32.

Eysenck, H. J., \& Eysenck, S. B. G. (1968b). The measurement of psychoticism: A study of factor stability and reliability. British Journal of Social and Clincial Psychology, 8, 69-76.

Eysenck, H. J., \& Eysenck, S. B. G. (1969). Personality structure and measurement. London: Routledge \& Kagan Paul.

Eysenck, H. J., \& Eysenck, S. B. G. (1975). Manual for the Eysenck Personality Questionnaire (adult and junior). San Diego, CA: Digits.

Eysenck, H. J., \& Eysenck, S. B. G. (1976). Psychoticism as a dimension of personality. London: Hodder \& Stoughton.

Eysenck, H. J., \& Eysenck, S. B. G. (1983). The cross-cultural study of personality. In C. D. Spielberger \& J. N. Butcher (Eds.), Advances in Personality Assessment (Vol. 2, pp. 41-69). Hillsdale, NJ: Lawrence Erlbaum.

Eysenck, H. J., \& Eysenck, S. B. G. (1991). Manual of the Eysenck Personality Scales (EPS Adult). London: Hodder \& Stoughton.

Eysenck, H. J., \& Rachman, S. (1965). The causes and cures of neurosis: An introduction to modern behaviour therapy based on learning theory and the principles of conditioning. London: Routledge \& K. Paul.

Eysenck, S. B. G. (1972). Junior Eysenck Personality Inventory: EdITS/Educational and Industrial Testing Service. San Diego, CA.

Eysenck, S. B. G., \& Eysenck, H. J. (1970). A factor-analytic study of the Lie Scale of the Junior Eysenck Personality Inventory. Personality, 1, 3-10.

Fanous, A., Gardner, C. O., Prescott, C. A., Cancro, R., \& Kendler, K. S. (2002). Neuroticism, major depression and gender: A population-based twin study. Psychological Medicine, 32, 719-728.

Floderus-Myrhed, B., Pedersen, N., \& Rasmuson, I. (1980). Assessment of heritability for personality, based on a short-form of the Eysenck Personality Inventory: a study of 12,898 twin pairs. Behavior Genetics, 10, 153-162.

Fullerton, J., Cubin, M., Tiwari, H., Wang, C., Bomhra, A., Davidson, S., et al. (2003). Linkage analysis of extremely discordant and concordant sibling pairs identifies quantitative-trait loci that influence variation in the human personality trait neuroticism. American Journal of Human Genetics, 72, 879-890.

Gillespie, N. A., Evans, D. M., Wright, M. J., \& Martin, N. G. (2004). Genetic Simplex modeling of Eysenck's dimensions of personality in a sample of young Australian twins. Twin Research, 7, 737-648.

Gillespie, N. G., Johnstone, S., Boyce, P., Heath, A. C., \& Martin, N. G. (2001). The genetic and environmental relationship between the Interpersonal Sensitivity Measures (IPSM) and the personality dimensions of Eysenck and Cloninger. Journal of Personality and Individual Differences, 31, 1039-1051. 
Ginns, E. I., St Jean, P., Philibert, R. A., Galdzicka, M., Damschroder-Williams, P., Thiel, B., et al. (1998). A genome-wide search for chromosomal loci linked to mental health wellness in relatives at high risk for bipolar affective disorder among the Old Order Amish. Proc Natl Acad Sci USA, 95, 15531-15536.

Golimbet, V. E., Gritsenko, I. K., Alfimova, M. V., \& Ebstein, R. P. (2005). Polymorphic markers of the dopamine D4 receptor gene promoter region and personality traits in mentally healthy individuals from the Russian population. Genetika, 41, 966-972.

Hay, D. A., Martin, N. G., Foley, D., Treloar, S. A., Kirk, K. M., \& Heath, A. C. (2001). Phenotypic and genetic analyses of a short measure of psychosisproneness in a large-scale Australian twin study. Twin Research, 4, 30-40.

Heath, A. C., Bucholz, K. K., Madden, P. A., Dinwiddie, S. H., Slutske, W. S., Bierut, L. J., et al. (1997). Genetic and environmental contributions to alcohol dependence risk in a national twin sample: Consistency of findings in women and men. Psychological Medicine, 27, 1381-1396.

Heath, A. C., \& Martin, N. G. (1990). Psychoticism as a dimension of personality: A multivariate genetic test of Eysenck and Eysenck's psychoticism construct. Journal of Personality and Social Psychology, 58, 111-121.

Hill, E. M., Stoltenberg, S. F., Bullard, K. H., Li, S., Zucker, R. A., \& Burmeister, M. (2002). Antisocial alcoholism and serotonin-related polymorphisms: Association tests. Psychiatr Genet, 12, 143-153.

Himei, A., Kono, Y., Yoneda, H., Sakai, T., Koh, J., Sakai, J., et al. (2000). An association study between alcoholism and the serotonergic receptor genes. Alcohol Clin Exp Res, 24, 341-342.

Holmans, P., Zubenko, G., Crowe, R. R., DePaulo, J. R. Jr., Scheftner, W. A., Weissman, M. M., et al. (2004). Genomewide significant linkage to recurrent, early-onset major depressive disorder on chromosome 15q. American Journal of Human Genetics, 74, 1154-1167.

Jang, K. L., Livesley, W. J., \& Vernon, P. A. (1996). Heritability of the big five personality dimensions and their facets: A twin study. Journal of Personality, 64, 577-591.

Janowsky, D. S. (2001). Introversion and extroversion: implications for depression and suicidality. Curr Psychiatry Rep, 3, 444-450.

Jardine, R., Martin, N. G., \& Henderson, A. S. (1984). Genetic covariation between neuroticism and the symptoms of anxiety and depression. Genetic Epidemiology, 1, 89-107.

Jinks, J. L., \& Fulker, D. W. (1970). Comparison of the biometrical genetical, MAVA, and classical approaches to the analysis of human behavior. Psychological Bulletin, 73, 311-349.

Kaabi, B., Gelernter, J., Woods, S. W., Goddard, A., Page, G. P., \& Elston, R. C. (2006). Genome scan for loci predisposing to anxiety disorders using a novel multivariate approach: strong evidence for a chromosome 4 risk locus. Am $J$ Hum Genet, 78, 543-553.

Keller, M. C., Coventry, W. L., Heath, A. C., \& Martin, N. G. (2005). Widespread evidence for non-additive genetic variation in Cloninger's and Eysenck's personality dimensions using a twin plus sibling design. Behavior Genetics, 35, 707-721. 
Kendler, K. S., Neale, M. C., Kessler, R. C., Heath, A. C., \& Eaves, L. J. (1993). A longitudinal twin study of personality and major depression in women. $A r-$ chives of General Psychiatry, 50, 853-862.

Kirk, K. M., Birley, A. J., Statham, D. J., Haddon, B., Lake, R. I., Andrews, J. G., et al. (2000). Anxiety and depression in twin and sib pairs extremely discordant and concordant for neuroticism: Prodromus to a linkage study. Twin Research, 3, 299-309.

Kuo, P. H., Neale, M. C., Riley, B. P., Patterson, D. G., Walsh, D., Prescott, C. A., et al. (2007). A genome-wide linkage analysis for the personality trait neuroticism in the Irish affected sib-pair study of alcohol dependence. Am J Med Genet B Neuropsychiatr Genet, 144, 463-468.

Lake, R. I. E., Eaves, L. J., Maes, H. M., Heath, A. C., \& Martin, N. G. (2000). Further evidence against the environmental transmission of individual differences in Neuroticism from a collaborative study of 45850 twins and relatives on two continents. Behavior Genetics, 30, 223-233.

Lander, E., \& Kruglyak, L. (1995). Genetic dissection of complex traits: guidelines for interpreting and reporting linkage results. Nature Genetics, 11, 241-247.

Levinson, D. F. (2006). The genetics of depression: a review. Biol Psychiatry, 60, 84-92.

Levitan, R. D., Masellis, M., Basile, V. S., Lam, R. W., Jain, U., Kaplan, et al. (2002). Polymorphism of the serotonin-2A receptor gene (HTR2A) associated with childhood attention deficit hyperactivity disorder (ADHD) in adult women with seasonal affective disorder. $J$ Affect Disord, 71, $229-233$.

Livesley, W. J. (2007). A framework for integrating dimensional and categorical classifications of personality disorder. Journal of Personality Disorders, 21, 199-224.

Loehlin, J. C. (1982). Are personality traits differentially heritable? Behavior Genetics, 12, 417-428.

Loehlin, J. C. (1985). Fitting heredity-environment models jointly to twin and adoption data from the California Psychological Inventory. Behavior Genetics, 15, 199-221.

Loehlin, J. C., Horn, J. M., \& Willerman, L. (1981). Personality resemblance in adoptive families. Behavior Genetics, 11, 309-330.

Loehlin, J. C., \& Nichols, R. C. (1976). Heredity, environment and personality: A study of 850 sets of twins. Austin: University of Texas Press.

Macaskill, G. T., Hopper, J. L., White, V., \& Hill, D. J. (1994). Genetic and environmental variation in Eysenck Personality Questionnaire scales measured on Australian adolescent twins. Behavior Genetics, 24, 481-491.

Marlow, A. J., Fisher, S. E., Francks, C., MacPhie, I. L., Cherny, S. S., Richardson, A. J., et al. (2003). Use of multivariate linkage analysis for dissection of a complex cognitive trait. American Journal of Human Genetics, 72, 561-570.

Martin, N., Boomsma, D., \& Machin, G. (1997). A twin-pronged attack on complex traits. Nature Genetics, 17, 387-392.

Martin, N., Goodwin, G., Fairburn, C., Wilson, R., Allison, D., Cardon, L. R., et al. (2000). A population-based study of personality in 34,000 sib-pairs. Twin Research, 3, 310-315. 
Martin, N. G., Eaves, L. J., \& Fulker, D. W. (1979). The genetical relationship of impulsiveness and sensation seeking to Eysenck's personality dimensions. Acta Geneticae Medicae et Gemellologiae (Roma), 28, 197-210.

Mata, I., Arranz, M. J., Patino, A., Lai, T., Beperet, M., Sierrasesumaga, L., et al. (2004). Serotonergic polymorphisms and psychotic disorders in populations from North Spain. Am J Med Genet B Neuropsychiatr Genet, 126, 88-94.

McGregor, B., Pfitzner, J., Zhu, G., Grace, M., Eldridge, A., Pearson, J., et al. (1999). Genetic and environmental contributions to size, color, shape, and other characteristics of melanocytic naevi in a sample of adolescent twins. Genetic Epidemiology, 16, 40-53.

Michaelis, W., \& Eysenck, H. J. (1971). The determination of personality inventory factor patterns and intercorrelations by changes in real-life motivation. $J$ Genet Psychol, 118, 223-234.

Middeldorp, C. M., Hottenga, J. J., Slagboom, P. E., Sullivan, P. F., de Geus, E. J., Posthuma, D., et al. (2007). Linkage on chromosome 14 in a genomewide linkage study of a broad anxiety phenotype. Mol Psychiatry, 13(1), 84-89.

Miller, S. A., Dykes, D. D., \& Polesky, H. F. (1988). A simple salting out procedure for extracting DNA from human nucleated cells. Nucleic Acids Research, 16, 1215.

Munafo, M. R., Yalcin, B., Willis-Owen, S. A., \& Flint, J. (2007). Association of the Dopamine D4 Receptor (DRD4) gene and approach-related personality traits: Meta-analysis and new data. Biological Psychiatry.

Nash, M. W., Huezo-Diaz, P., Williamson, R. J., Sterne, A., Purcell, S., Hoda, F., et al. (2004). Genome-wide linkage analysis of a composite index of neuroticism and mood-related scales in extreme selected sibships. Human Molecular Genetics, 13, 2173-2182.

Neale, B. M., Sullivan, P. F., \& Kendler, K. S. (2005). A genome scan of neuroticism in nicotine dependent smokers. American Journal of Medical Genetics. Part B, Neuropsychiatric Genetics, 132, 65-69.

Neale, M. C. (1999). Mx: Statistical Modelling (5th ed.). Box 126 MCV, Richmond, VA 23298: Department of Psychiatry.

Neale, M. C., \& Cardon, L. R. (1992). Methodology for genetic studies of twins and families. Dordrecht: Kluwer Academic Publishers.

Ni, X., Bismil, R., Chan, K., Sicard, T., Bulgin, N., McMain, S., et al. (2006). Serotonin $2 \mathrm{~A}$ receptor gene is associated with personality traits, but not to disorder, in patients with borderline personality disorder. Neuroscience Letters, 408, 214-219.

Norton, N., \& Owen, M. J. (2005). HTR2A: association and expression studies in neuropsychiatric genetics. Ann Med, 37, 121-129.

Ogdie, M. N., Fisher, S. E., Yang, M., Ishii, J., Francks, C., Loo, S. K., et al. (2004). Attention deficit hyperactivity disorder: fine mapping supports linkage to 5p13, 6q12, 16p13, and 17p11. Am J Hum Genet, 75, 661-668.

Ormel, J., \& Rijsdijk, F. V. (2000). Continuing change in neuroticism during adulthood structural modelling of a 16-year, 5-wave community study. Personality and Individual Differences, 28, 461-478. 
Pedersen, N. L., Plomin, R., McClearn, G. E., \& Friberg, L. (1988). Neuroticism, extraversion, and related traits in adult twins reared apart and reared together. Journal of Personality and Social Psychology, 55, 950-957.

Posthuma, D., Beem, A. L., De Geus, E. J. C., Van Baal, G. C. M., Von Hjelmborg, J. B., Iachine, I., et al. (2003). Theory and practice in quantitative genetics. Twin Research, 6, 361-376.

Price, R. A., Vandenberg, S. G., Iyer, H., \& Williams, J. S. (1982). Components of variation in normal personality. Journal of Personality and Social Psychology, 42, 328-340.

Risch, N., \& Zhang, H. (1995). Extreme discordant sib pairs for mapping quantitative trait loci in humans. Science, 268, 1584-1589.

Rose, R. J., \& Kaprio, J. (1988). Frequency of social contact and intrapair resemblance of adult monozygotic cotwins-or does shared experience influence personality after all? Behavior Genetics, 18, 309-328.

Rose, R. J., Kaprio, J., Williams, C. J., Viken, R., \& Obremski, K. (1990). Social contact and sibling similarity: Facts, issues, and red herrings. Behavior Genetics, 20, 763-778.

Rose, R. J., Koskenvuo, M., Kaprio, J., Sarna, S., \& Langinvainio, H. (1988). Shared genes, shared experiences, and similarity of personality: Data from 14,288 adult Finnish co-twins. Journal of Personality and Social Psychology, 54, 161-171.

Roy, A. (1998). Is introversion a risk factor for suicidal behaviour in depression? Psychol Med, 28, 1457-1461.

Saudino, K. J., Pedersen, N. L., Lichtenstein, P., McClearn, G. E., \& Plomin, R. (1997). Can personality explain genetic influences on life events? Journal of Personality and Social Psychology, 72, 196-206.

Scarr, S., Webber, P. L., Weinberg, R. A., \& Wittig, M. A. (1981). Personality resemblance among adolescents and their parents in biologically related and adoptive families. Progress in Clinical and Biological Research, 69 Pt B, 99-120.

Self, S. G., \& Liang, K. Y. (1987). Asymptotic properties of maximum likelihood estimator and likelihood ratio tests under nonstandard conditions. Journal of the American Statistical Association, 82, 605-610.

Shields, J. (1962). Monozygotic twins. Oxford: Oxford University Press.

Shifman, S., Bhomra, A., Smiley, S., Wray, N. R., James, M. R., Martin, N. G., et al. (2007). A whole genome association study of neuroticism using DNA pooling. Mol Psychiatry, 13, 302-312.

Sipe, J. C., Chiang, K., Gerber, A. L., Beutler, E., \& Cravatt, B. F. (2002). A missense mutation in human fatty acid amide hydrolase associated with problem drug use. Proc Natl Acad Sci USA, 99, 8394-8399.

Tellegen, A., Lykken, D. T., Bouchard, T. J. Jr., Wilcox, K. J., Segal, N. L., \& Rich, S. (1988). Personality similarity in twins reared apart and together. Journal of Personality and Social Psychology, 54, 1031-1039.

Thorgeirsson, T. E., Oskarsson, H., Desnica, N., Kostic, J. P., Stefansson, J. G., Kolbeinsson, H., et al. (2003). Anxiety with panic disorder linked to chromosome $9 \mathrm{q}$ in Iceland. American Journal of Human Genetics, 72, 1221-1230. 
Tochigi, M., Umekage, T., Kato, C., Marui, T., Otowa, T., Hibino, H., et al. (2005). Serotonin $2 \mathrm{~A}$ receptor gene polymorphism and personality traits: no evidence for significant association. Psychiatr Genet, 15, 67-69.

Trull, T. J., Tragesser, S. L., Solhan, M., \& Schwartz-Mette, R. (2007). Dimensional models of personality disorder: Diagnostic and Statistical Manual of Mental Disorders Fifth Edition and beyond. Current Opinions in Psychiatry, 20, 52-56.

Urata, T., Takahashi, N., Hakamata, Y., Iijima, Y., Kuwahara, N., Ozaki, N., et al. (2007). Gene-gene interaction analysis of personality traits in a Japanese population using an electrochemical DNA array chip analysis. Neuroscience Letters, 414, 209-212.

van den Oord, E. J. (2005). Controlling false discoveries in candidate gene studies. Molecular Psychiatry, 10, 230-231.

van den Oord, E. J., \& Sullivan, P. F. (2003). A framework for controlling false discovery rates and minimizing the amount of genotyping in the search for disease mutations. Human Heredity, 56, 188-199.

Viken, R. J., Rose, R. J., Kaprio, J., \& Koskenvuo, M. (1994). A developmental genetic analysis of adult personality: Extraversion and neuroticism from 18 to 59 years of age. Journal of Personality and Social Psychology, 66, $722-730$.

Wainwright, M. A., Wright, M. J., Geffen, G. M., Luciano, M., \& Martin, N. G. (2005). The genetic basis of academic achievement on the Queensland Core Skills Test and its shared genetic variance with IQ. Behavior Genetics, 35, 133-145.

Watson, D., \& Clark, L. A. (1984). Negative affectivity: The disposition to experience aversive emotional states. Psychological Bulletin, 96, 465-490.

Williams, J. T., \& Blangero, J. (1999). Power of variance component linkage analysis to detect quantitative trait loci. Annals of Human Genetics, 63, 545-563.

Wray, N. R., Birley, A. J., Sullivan, P. F., Visscher, P. M., \& Martin, N. G. (2007). Genetic and phenotypic stability of measures of neuroticism over 22 years. Twin Res Hum Genet, 10, 695-702.

Wright, M. J., Hansell, N. K., Geffen, G. M., Geffen, L. B., Smith, G. A., \& Martin, N. G. (2001). Genetic influence on the variance in P3 amplitude and latency. Behavior Genetics, 31, 555-565.

Wright, M. J., \& Martin, N. (2004). The Brisbane Adolescent Twin Study: Outline of study methods and research projects. The Australian Journal of Psychology, 56, 65-78.

Zhu, G., Duffy, D. L., Eldridge, A., Grace, M., Mayne, C., O’Gorman, L., et al. (1999). A major quantitative-trait locus for mole density is linked to the familial melanoma gene CDKN2A: A maximum-likelihood combined linkage and association analysis in twins and their sibs. American Journal of Human Genetics, 65, 483-492.

Zhu, G., Evans, D. M., Duffy, D. L., Montgomery, G. W., Medland, S. E., Gillespie, N. A., et al. (2004). A genome scan for eye color in 502 twin families: Most variation is due to a QTL on chromosome 15q. Twin Research, 7, 197-210. 
Zohar, A. H., Dina, C., Rosolio, N., Osher, Y., Gritsenko, I., Bachner-Melman, R., et al. (2003). Tridimensional personality questionnaire trait of harm avoidance (anxiety proneness) is linked to a locus on chromosome 8p21. American Journal of Medical Genetics, 117B, 66-69.

Zuckerman, M. (1999). Vulnerability to psychopathology: A biosocial model. Washington, DC: American Psychological Association.

Zuckerman, M., Kuhlman, D. M., Joireman, J., Teta, P., \& Kraft, M. (1988). What lies beyond $\mathrm{E}$ and $\mathrm{N}$ ? Factor analyses of scales believed to measure basic dimensions of personality. Journal of Personality and Social Psychology, 54, 96-107. 
1446 